George R. Wilkes

University of Edinburgh

Project on Religion and Ethics

in the Making of War and Peace

grw1000@gmail.com

DOI: 10.18485/rit.2021.19.36.9
UDK: 172.4

$355.01: 2-42$

Originalni naučni rad

Datum prijema: 07.06.2021.

\title{
ETHICS, RELIGION \\ AND HUMAN/E LIMITS IN WAR
}

\begin{abstract}
Summary
This essay shows how changing ways of thinking about love and fear in armed combat have shaped intellectual responses to ethical behaviour in war. While there is a voluminous literature on the importance of reasoning in just war literature, the history of thinking about justice, ethics and war is also shaped by reflection on the role of love and fear in war, as existential emotions rather than as abstract principles. As reflection on ethics in war has increasingly taken on secular forms, the impression of prior religious traditions continues to play important roles. The essay shows how modern and contemporary responses to war can use multidisciplinary enquiries in order to bridge the gaps between factors that can be rationalised, and emotions related to love and fear, which demand more humanistic analytical approaches. The final part of the essay shows how such multidisciplinary enquiries have been used since 1945 in changing military education, and particularly in the development of new forms of ethics education in the military and in the changing focus of efforts by the International Committee of the Red Cross (ICRC) to disseminate the values which protect people in war thanks to the development of International Humanitarian Law.
\end{abstract}

Key words: war, ethics, military ethics, just war, love and fear, Franz Rosenzweig, Michael Walzer, ICRC.

Love and fear have framed many of the most influential publications about the need for humans to agree war has limits. In the Five Books of Moses, one of the clearest deliberations on the nature and purpose of war is presented in Deuteronomy 20, which is framed by the fear of battle, and the fear of the consequences of death in battle for loved ones left at home. In Deuteronomy 21, the commandment which we could now describe as prohibiting rape in warfare - the laws relating to the 'beautiful' female captive - is often presented as a limitation imposed on men in warfare, recognising warfare as an archetypal situation in which norms are broken, in which power, fear, passion, or simple irrationality overcome the most deeply embedded features of civilisation. In one of the most influential 
early Christian texts on war, Augustine relates to the subject in the context of the passions that drive humans, as individuals and as societies. Aquinas presented the bases of 'just war thinking' in his Summa Theologica, within his treatment of the topic 'love'. Through the history of reflections in which attempts are made to explain how war should be regulated, or limited, rational calculations of justice and practical realities are presented as requiring exceptional justification in the face of the human irrationality associated with war. Clausewitz, in his definitive work on modern strategy, On War, presents the contribution of passion and fear as a key feature of 'the fog of war', creating the 'friction' which he sees constantly acts to undermine attempts to govern warfare rationally. Love and fear may mix in reality on the battlefield, or in thinking about battlefield conditions, and this is of central importance in thinking about the kind of military norms and practices which militate against criminality, and against panic. Soldiers are taught that they fight for their fellow soldiers: since at least the Romans, this has historically been a central feature of the culture of warfare, and it has only received more attention in recent decades - thinking of the American notion of the Band of Brothers, for instance, and the place this has in teaching about ethical dilemmas in the military.

Both love and fear are widely presented as motivating transgressions of civilised norms. This may slip from view where war is treated as a matter for clear, cold reasoning: by strategists, by realists, by political ideologues.

My essay examines why love and fear are used in this way, across cultures, and why they also remain important in empirical and objectifying attempts to describe how limits in war can be effectively embraced by military professionals. A body of academic literature has sought to present the core problems addressed in philosophical and religious literature on war as essentially common, at heart focused on the human and the inhumane (see e.g. Rodin and Sorabji 2006; Nardin 1996). We may instead explore the extent to which thinking about the limits of war varies over time, across cultures and religions, and between the discourses and positions which reflect the interests of different political actors. The field is less clear than appears to be the case in the simplest treatments of the subject, though the reason for underlining the commonalities across cultures and religions worth appreciating: norms are stronger for being held in common and to the extent that they are understood to be clear. A level of further complication arises in understanding how rules are respected, or not respected, in practice - the social and psychological factors which provide context for practical, professional and technological issues that may make rules appear distant or difficult to apply. To examine the extent to which broadly common features of human civili- 
sation make a difference in the practical treatment of human beings in war implies exactly the kind of interdisciplinary work that the Centre for Empirical Research on Religion has been conducting for some decades, engaging with tools from both objective sciences and humanistic disciplines focused on subjective realms. I will review both historical and current attempts to promote understanding of the limits of war with this multidisciplinary interest in mind, and return to that in the conclusions.

\section{Love and fear - unsettling the separate disciplinary discourses on war}

In modern times, the blinkers of disciplinary silos and professional specialisms have brought new and often narrower perspectives on questions about the nature of war, its purpose and its human consequences. At the same time, the immensity of the suffering imposed in contemporary wars has also prompted interrogations of rationalistic or utilitarian accounts, insisting on wider accounts that take seriously the effect of the emotions raised in wartime. Indeed, the fact that emotions connected with love and fear play such a debilitating role in war has brought the entire Western philosophical canon into question - a development which became marked in responses to the First World War, and this may be seen in a wide variety of cultural and intellectual works from across Europe at this time, and from thinkers of all religious traditions (as from atheists, too). One such voice, the German Jewish philosopher Franz Rosenzweig (1886-1929), argued that the First World War demanded a new thinking, embracing a new sensitivity to the sense of self we carry that is vulnerable to fanatical types of nationalistic love, and to absolutist, fanatical responses to fear (Rosenzweig 1921). Before the war, Rosenzweig had already developed a critique of idealist philosophy - of Hegelian and post-Kantian thought - which he held to account for distancing Europeans from their real selves in pursuit of abstract political projects and identities. Nevertheless, Rosenzweig had also been enthusiastic at the outbreak of war, joined up in the German army, and went to serve on the Macedonian front, near Skopje, and also briefly in Poland. In these locations, he sketched out a synthetic multidisciplinary philosophical work, The Star of Redemption (Stern der Erlösung), written up after the war, and then published in 1921.

The Star of Redemption begins with the contention that the fear of death should unsettle the aspiration to define our world through abstract philosophy an abstract philosophy which he subsequently shows motivates fanatical and idolatrous thinking, turning the battlefield into a testing ground for tragic, pagan con- 
flicts, and creating societies which lionize eternal youth. There is something of Kierkegaard's reflection on 'fear and trembling' in Rosenzweig's depiction of worldly existence, though his 'new thinking' instead of leaping for a personal faith commitment argues for a grounded realism about who we are, about our needs. Instead of abstract philosophy or theology, he contends, we need to work first with anthropology. The Star of Redemption unfolds its reflections on Jewish and Christian normative commitments only after pressing for a realistic re-engagement with the foundations of what we can know about our place in the world. All of the sciences are pressed into service in his schema, which underlines why it is that, without a new approach to thinking, love and fear are inescapable but insufficient guides for our deepest commitments. Blind love, he argues, also motivates fanatical and pagan thinking, the nationalisms and patriotisms that demand the sacrifice of humanity through pure but idolatrous idealism, idolatrous because they operate through the sanctification of abstract, distant concepts which do not allow for the full appreciation of real lives (Rosenzweig 1921, p. 268-272, 274-75).

To arrive at a realistic sense of self-worth, according to Rosenzweig, we do not need to start with theory or intellectual accomplishment. Instead, he encourages his reader to think about themselves as real people preserving a sense of self through their private lives, through their care for themselves. In his own account, Rosenzweig found this in his encounters with local Jews in Skopje and in Poland, people who he believed to have this natural sense of themselves, which he - the very lost 'Western' intellectual - admired. Seen in this light, the call to death in battle, to glorious martyrdom, is fanatical not because it is pagan, but because it destroys what is real in the pagan life by taking it as a basis for understanding the Absolute, or 'the All'. The Star of Redemption links Judaism and Christianity with a critique of thinking in categories of total conviction - hope comes not through blind idealism but through realistic responses to human needs.

The Star of Redemption turns to war obliquely in describing the tragic, distant reflection of personhood which motivates the sanctification of pagan values: of Siegfried's eternal youthfulness, displayed in martial heroism (Rosenzweig 1921, p. 329). Once Rosenzweig has established that the loneliness of the individual in society does not require a leap towards absolutist incarnations of political and social ideals, he returns to war again. War is a response to human distance - and idealism - blind, abstract love - magnifies that distance, with tragic results. Killing relies on distance - a theme we return to afresh in our day too. War relies on objectifying distance, and fanatical approaches to war rely on an unfeeling, unthinking embrace of objectifying ourselves and our enemies. Where instead 
community is built, it creates relationships that embody a sense of closeness, of being near rather than far. This is the realm in which conflict should be dealt with, through politics, through conversation. In their commentary on Deuteronomy 20, the ancient rabbis were wise, Rosenzweig, argues, to reject war as an option within a country, or where there is a possibility of tangible political community. They were wise to view war realistically, resisting the temptation to sanctify war at all - as he saw it, they wisely left 'holy war', by which he may have been referring to biblical war, firmly in the past (Rosenzweig 1921, 329-331).

The struggle to identify what the 'realities of war' are has motivated renewed normative enquiry thanks to the secularisation of 'just war thinking' after the Second World War. We may see in recent secular literature on the limitations of 'just wars' an engagement with questions about love and fear that extends earlier existentialist reflections, albeit sometimes obliquely, as in Michael Walzer's Just and Unjust Wars (1977), which has such exercised a huge influence on Anglo-Saxon thinking about war that it is fair to say it remains a definitive work for thinking about military ethics, both in the ivory tower and in the military academy. Walzer's essay self-consciously crosses disciplinary boundaries, in an effort to underline that an economistic, or reductionist, approach to ethical calculations in war - what passed for 'realism' among different schools of philosophers writing on the subject - was insufficient (pp. xiii, 3-20). Walzer's reflection is not insistent on the secular foundation that he works with - he deliberately 'admires' religious works from Jewish and Christian traditions - but he does offer a new conceptual framework for understanding ethics on the battlefield taking account of developments since the League of Nations and its successor, the United Nations, had outlawed aggressive war, and in light of the passage and almost universal ratification of the Geneva Conventions. A key to the new foundation he describes is the 'moral equality' of combatants (p. 34f.), an ethic which reflects the separation of soldiers from society, the military professional from the murderer, and acts of defence from war crimes. In the terms used in the just war discourse, this reflects the separation between jus ad bellum and jus in bello, particularly through the Geneva Conventions, but more broadly through the overlapping legal paradigms applied to war, international humanitarian law and the laws of armed conflict, or the laws of war. The moral equality of combatants is not a purely legal convention, however - rather it reflects the common peril that combatants face, and their recognition of each other's vulnerability and humanity. Walzer illustrates this with stories of soldiers who protest orders to violate the laws of war (p. 45), and of others who, on seeing the enemy close up, as a hu- 
man, refuse to shoot (p. 138f.). For Walzer, this existential encounter (and not a legal convention alone) is the boundary that distinguishes between killing in defence and brutal murder.

In contrast to Aquinas, love is not the term of art through which Walzer frames the basis for societies to commit to common defence, but through the book there appears a recurrent appeal - and this could be an appeal to 'love' but by another name to the loyalties and to the feelings of justice held by communities. Walzer is well known for dismissing the claim that he is a communitarian, though the claims of community frame crucial discussions in Just and Unjust Wars, among others the justification for military interventions in response to humanitarian outrages (pp. 101-108). Whereas the communitarians with whom Walzer is compared - Alasdair MacIntyre, for instance - describe communities whose language does not fully translate to wider secular society, Just and Unjust Wars clearly sets out to explore a moral basis for the convention of armed defence which transcends cultural and religious diversity. 'Love' remains significant, and even central, for many Christian (and Jewish and Muslim) thinkers seeking to discern criteria for justified military conduct, both among those who prefer the conceptual framework of a 'just peace' and those who view 'just war' thinking as a better tool for determining ethical responses to unjust violence. It remains a visible resource, too, in more secular reflection motivated by the necessity of an ethic of care, by the importance of relationship, of gender-sensitive and feminist approaches, and in work by thinkers focused on practice and the process of discernment. Academic and public debate about the nature of war today is increasingly pluralistic, drawing secular and religious thinkers into discussion with their respective premises and innovations, and encompassing a range of perspectives on justifications for force and for non-violent and pacifist choices too, again requiring discussants to reflect on what differs and what is held in common across the range of positions under discussion.

\section{Studying care, emotions and effective military ethics education}

That soldiers fail to conform to professional norms under the stress of battlefield conditions has been a rationale for successive reforms of the education given to militaries since the Vietnam War. The need for multidisciplinary study to address this with more sophistication has long marked the work of the networks of educators who have pressed for new forms of military ethics education in Western military academies in the last 20 years. 
When deliberate attempts to reform professional military ethics education were initiated in the 1990s, educators had resort to at least two kinds of account of military failures. First, across NATO countries, educators cite the classic account of the need for professional military education based on the study of S.L.A. Marshall (1947) on the unwillingness of American soldiers to kill. Marshall's insight uncovered the extent to which soldiers facing combat do not want to kill, they need to be trained to kill. Following Marshall's work, military researchers showed that training reforms since the Second World War reduced the proportion of soldiers who failed to fire in the face of the enemy. This training has an ideological component, and a practical component - basic training involves exercises in militaries the world over in which individuals are presented with sacks, or targets, or other models of humans, which trainees are exhorted to kill, often shouting (e.g. 'kill') as they prepare themselves and then execute the task. Since 1945, combatants the world over have increasingly been focused on additional reasoning that can justify a separation between necessary killing and murder, this being the basis of the military as a profession. During the Cold War, this relied on techniques that dehumanise the enemy. Since the 1990s, a more careful representation of what military professionalism involves has spread in military academies across the world, entailing a critical perspective on what military ethics involves (see, e.g., Robinson 2008).

The background to this shift may be found in a range of factors. The twentieth century development of self-defence as the only reason for war accepted in international law continues to have an impact on military education. The technological development of the contemporary military has provided pressure for professionalisation. Individuals, even in the more junior ranks (debate about how far this goes was ignited by Krulak 1999), are required to take an ever-wider range of decisions, facing battlefield conditions, with life-or-death consequences. In countries in which national military service has been reduced or ended altogether, a gap between the professionalising military and the public has developed, which encourages reflection on the special role of the military and on expectations for mutual relationships at a social and a political level. The pressure on this relationship rises when militaries are sent on missions abroad, and all the more so when war crimes are exposed. After the Mai Lai massacre in Vietnam, the US military came under increased pressure to reform its ethics education for officers, and with the exposure of atrocities committed in Bosnia, Iraq and Afghanistan, a large proportion of the militaries in or allied to the NATO alliance have enhanced the role of ethics education for all ranks. 
The educators teaching ethics in the military are aware that the adherence of military units and individuals to arguments for restraint in the use of force - arguments which may represent accepted and enforced military doctrine - breaks down under pressure. They therefore need to understand how military professionalism can be supported on other grounds. Military professionals are trained to kill in self-defence, and in defence of those closest too them - a contemporary framing of the idea that love conquers when fear and uncertainty erodes other grander rational calculations. In the USA, the extent to which the defence of the band of brothers is widely acknowledged to be the primary reason for which many arms bearers are willing to use their weapons in the chaotic conditions of contemporary war. The conditions in which this can lead to abuses of the dangerous 'other' have been clear, and researchers have sought to use a wide range of sciences and humanities in order to clear the way for militaries to be able to insist on courageous conduct and restraint as a standard for professionals to use their weapons under pressure.

Even as contemporary warfare has been transformed by new technological powers, the need for research on the nature of military professionalism to integrate both sciences and humanities became more - and not less - obvious. Ethicists turn to psychologists and to neuroscientists to understand the ways in which fear and love regulate battlefield instincts and decision-making powers, and yet understanding of the integration of rational and instinctive processes required for members of a military hierarchy to avoid brutality is very much dependent on the complex of social phenomena which make up military units. This is insisted upon in the works of one of the most prominent researchers focused on military ethics, Shannon French, who has conducted interesting work that shows how neurological regulation can support the essentially social nature of militaries seeking to conform to warrior codes (French 2015). 'The human factor' therefore remains the domain of neither the humanists nor the scientists alone. French shows how the latest technologies used to transform the study and practice of contemporary warfare at a 'distance' do not remove the requirement of human control in the face of uncertainty, in what conventionally modern militaries saw as the main justification for human control of mission decisions, the 'fog of war' (see, e.g., French 2021).

This social dimension of the human factor has been reviewed repeatedly by researchers commissioned by the International Committee of the Red Cross (ICRC) to investigate how transgressions of international humanitarian law happen, and how military hierarchies may best embed respect for the law and re- 
straint in the use of arms throughout their forces. In 2004, the ICRC saw the need to revise its approach to teaching about respect for the Geneva Conventions with a set of social and psychological scientific tools that would impress itself on the modernising militaries of the time. The Roots of Behaviour in War (2004) focused on the psychology of group behaviour in the military, presenting arguments for the integration of lessons about international humanitarian law through military institutions, with a focus on the role to be played by military hierarchies, and the role of consistent enforcement of the law, punishing breaches of the law deliberately. By 2018, the science behind The Roots of Behaviour in War appeared too behaviouralist, reducing what could be known about motivations for respecting the law to negative motivations (notably fear). A new set of studies were commissioned, leading to the publication of The Roots of Restraint in War (2018) on the basis of which the ICRC's work with militaries around the world could be redirected. Working with trainers within the American, Australian and Philippines militaries, tests of the motivation for restraint under conditions of stress were shown to reflect positive motivations for ethical conduct - the basis for respect for civilian, humanitarian needs was reinforced effectively through reference to the social identity at the heart of the military's mission, and this could be extended to non-state armed actors whose relationships with community identities were seen as less conditioned by the hierarchies of a conventional military. Teaching respect for the law is not presented as dependent on punishment and hierarchy alone, it is most effectively reinforced by reference to the positive emotions ('love') associated with the communities for whom militaries fight. The identities in question differ across militaries, and the cultures or language required to promote respect for the law must therefore vary as well.

\section{Conclusions}

The framework in which ethics in war are discussed today is increasingly a secular one, pluralistic, as we have seen, yet drawing scholars and the political and military communities which oversee military education to revise the language used about love and fear in response to contemporary realities. The attempts of the scholarly community to think about the limits of war, and the attempts of the ICRC and of modern military academies to limit war crimes, require renewed approaches to thinking about the ways in which love and fear are regulated in political conflicts and in battlefield conditions. They are based on sophisticated interdisciplinary research, drawing on psychology, on sociolo- 
gy, on law, on political thought - and these projects to define war will continue to use disciplines which embrace the social nature of the human factor, the subjective and the contextual, meaning anthropology, or cultural studies, history, or the arts. The drive to define ethical norms and practices in an objective fashion is multifaceted: objective law and objective science have a persuasive force which is intended to match up to the moral dangers of warfare, to the chaos and degradation, and to the subversion of human value in distant, technological conflicts. What may be attained by embracing an objective framework for thinking about humanity and inhumanity in war is a tool for objective scientific study and realistic application. Yet, as Rosenzweig, and Kierkegaard, and many others, have noted, love and fear are not objective, measurables; they respond to a relative distance, not an objective distance; and they are products of a sense of self which is not a stable quantity. Those who care to limit inhumanity in war will continue to require new multidisciplinary studies which address these components, the relational and the subjective and the contextual. The human element, a reason for which many religious and secular humanists embrace pacifism, cannot effectively be lightly skipped over in an attempt to persuade public opinion that new wars can now be humanely fought with an objective, rational, high-tech precision. I encourage readers to see how much of the corpus of works produced by CEIR has advanced the study of the relationships across scientific, cultural and social communities and perspectives, which is a central feature of the reality which will mean that the character of war continues to be contested in our immediate future. 


\section{Bibliography}

Nigel Biggar, In Defence of War (Oxford: Oxford University Press, 2013).

Susan Brooks Thistlethwaite, ed., Interfaith Just Peacemaking: Jewish, Christian, And Muslim Perspectives On The New Paradigm Of Peace And War (London: Palgrave Macmillan, 2021).

Shannon E. French and Anthony I. Jack, 'Dehumanizing the Enemy: The Intersection of Neuroethics and Military Ethics', in David Whetham and Bradley J. Strawser, eds, Responsibilities to Protect: Perspectives in Theory and Practice, The Hague/Boston: Brill/Martinus Nijhoff Publishers, 2015, pp. 169-195.

Shannon E. French and Lisa N. Lindsay, 'Artificial Intelligence in Military Decision Making: Avoiding Ethical and Strategic Perils with an Option-Generator Model', in Bernard Koch and Richard Schoonhoven, eds, The Ethical Implications of Emerging Technologies in Warfare, The Hague/Boston: Brill/Martinus Nijhoff Publishers, 2021 (forthcoming).

International Committee of the Red Cross, The Roots of Behaviour in War: A Review of the Literature (Geneva: ICRC, 2004).

International Committee of the Red Cross, The Roots of Restraint in War (Geneva: ICRC, 2018).

Charles C. Krulak, 'The Strategic Corporal: Leadership in the Three Block War', Marines Corps Gazette, 83/1 (January 1999), pp. 18-23.

Eli S. McCarthy, ed., A Just Peace Ethic Primer: Building Sustainable Peace and Breaking Cycles of Violence (Washington D.C.: Georgetown University Press, 2021).

S.L.A. Marshall, Men Against Fire: The Problem of Battle Command, 1947/2012.

Terry Nardin, ed., The Ethics of War and Peace: Religious and Secular Perspectives (Princeton N.J.: Princeton University Press, 1996).

Paul Robinson et al, eds, Ethics Education in the Military (Aldershot/Burlington VT: Ashgate, 2008).

Franz Rosenzweig, The Star of Redemption (1921; English translation, London: Littman Library/Routledge, 1970).

Richard Sorabji and David Rodin (eds), The Ethics of War: Shared Problems in Different Traditions (Aldershot: Ashgate, 2006).

Michael Walzer, Just and Unjust Wars (New York, N.Y.L Basic Books, 1977).

Erik Wingrove-Haugland, 'The Ethics of Care and the Ethics of War', International Society for Military Ethics (ISME), 2015. https:/www.internationalsocietyformilitaryethics.org/uploads/5/3/8/9/53896955/wingrove-haugland_ethicsofcare_ethicsofwar.pdf 


\title{
George R. Wilkes \\ University of Edinburgh \\ Project on Religion and Ethics \\ in the Making of War and Peace \\ grw1000@gmail.com
}

\section{ETIKA, RELIGIJA I LJUDSKA OGRANIČENJA U RATU}

\begin{abstract}
Rezime
Esej pokazuje kako su promenjeni načini razmišljanja o ljubavi i strahu u oružanoj borbi oblikovali intelektualne odgovore na etičko ponašanje u ratu. Iako postoji obimna literatura o važnosti rasuđivanja u pravednoj ratnoj književnosti, istorija razmišljanja o pravdi, etici i ratu takođe je oblikovana promišljanjem o ulozi ljubavi i straha u ratu, kao egzistencijalnim emocijama, a ne kao apstraktnim načelima. Kako je promišljanje o etici u ratu sve više poprimalo sekularne oblike, utisak prethodnih religijskih tradicija nastavlja da igra važnu ulogu. Esej pokazuje kako moderni i savremeni odgovori na rat mogu koristiti multidisciplinarna pitanja radi premošćavanja jaza između faktora koji se mogu racionalizovati $i$ emocija vezanih za ljubav i strah, koje zahtevaju više humanističko-analitičke pristupe. Završni deo eseja pokazuje kako su se takva multidisciplinarna pitanja koristila od 1945. u promeni vojnog obrazovanja, a posebno u razvoju novih oblika etičkog obrazovanja $u$ vojsci $i$ u promenljivom fokusu napora Međunarodnog komiteta Crvenog krsta (ICRC) za širenje vrednosti koje štite ljude u ratu zahvaljujući razvoju međunarodnog humanitarnog prava.
\end{abstract}

Ključne reči: rat, etika, vojna etika, samo rat, ljubav i strah, Franz Rosenzweig, Michael Walzer, ICRC. 